\title{
CORPORATE SOCIAL RESPONSIBILITY REPORTING IN MINING SECTOR. THE EUROPEAN UNION PERSPECTIVE
}

\author{
Patrycja HĄBEK \\ Silesian University of Technology, Faculty of Organization and Management, Poland; patrycja.habek@polsl.pl, \\ ORCID: 0000-0002-7545-1637
}

Purpose: In this paper the author presents an overview of CSR reporting practices in general and then within the mining context.

Design/methodology/approach: analyzing the literature on the subject. Literature studies include Polish and foreign publications.

Findings: The EU Directive 2014/95/EU is the first step but there is a need for further steps directed towards unifying the principles and content of non-financial statements and getting the CSR reporting practices closer to financial ones to guarantee the reliability of the data disclosed in these areas.

Originality/value: There are presented some voluntary sectoral initiatives focused on sustainability issues in mining industry as well as sustainability reporting guidelines of Global Reporting Initiative with its mining and metals sector supplement. The second part of the paper discusses the activities of mandating the CSR reporting at European Union level through EU Directive 2014/95/EU which obliges certain large undertakings to prepare a non-financial statement containing information relating to corporate social responsibility aspects.

Keywords: CSR reporting, mining sector, EU Directive 2014/95/EU, GRI, self-regulations.

Category of the paper: General review.

\section{Introduction}

Clear and transparent communication should form the basis of a responsible organization. The core of the corporate social responsibility (CSR) concept does not lie in charitable activities or the collaboration of enterprises with non-governmental organizations, but primarily in the emphasis placed on the organizational commitment to transparency. The expectations of stakeholders towards a modern enterprise, taking into consideration its performance, transparency, and communication, have become quite high nowadays (Kuźbik, 2010). Therefore CSR communication is a central element in the relationship between a company and their stakeholders (Vurro, and Perrini, 2011). Only communication of both positive and 
negative results is able to prove that the behavior of a company can be considered as responsible and disclosure of real facts rather than successful stories which aim is just to improve company's image.

We are witnessing a global growth of demand for extracting minerals which will be generated in next years by the expected growth of world population, urbanization, and the increasingly higher living standards combined with higher consumption (OECD, 2011). Metals and minerals are present in our everyday lives, they provide the material base for many other businesses and industrial sectors. In Europe the extractive industry plays an integral role in wealth creation, quality of life and it is the sector through which Europe obtain materials which are crucial in the transition to Industry 4.0. We can say that the developments in all industries would not be possible without the raw materials provided through mining (Euromines, 2018). But the problem with the mining sector is that all mining companies share the same characteristic: they extract non-renewable resources from the environment (Bluszcz, 2017; Jenkins, 2004). Therefore, due to the limited resources of the planet, mining activities because of its nature, cannot be sustainable (Prior et al., 2012). The examples of negative effects of mining companies in local communities and environments include the release of toxic chemicals onto the land and into the waterways as well as the treatment of workers, indigenous populations, local villages, and developing nations (Peck, \& Sinding, 2003).

Despite the inglorious facts mining sector is trying its best to reduce its adverse impact on the natural environment and societies to become more sustainable. It undertakes many voluntary self-regulation activities and initiatives and also disclose information on how the companies from the sector implement the concept of social responsibility into operations (Wolniak, 2017). We must be aware that these voluntary activities do not result solely from internal motives of mining companies but are also the result of pressure exerted by various groups of stakeholders and the constant criticism of operations carried out by large and multinational mining enterprises.

The aim of the paper is to present the general view on corporate social responsibility reporting in the mining context emphasizing the perspective of European Union mandatory reporting of non-financial information introduced through the EU Directive 2014/95/EU.

\section{CSR reporting as a form of communication}

Corporate social responsibility (CSR) is a way of running a business, a concept which focuses on the impact of business activities on society and environment while taking into account the expectations of key stakeholders. Identification of stakeholders and their expectations and in next step assuring two-way communication with them is fundamental for a socially responsible company. The term stakeholders can be defined as individuals or groups 
of people inside and outside of an organization which have an impact on or can be influenced by the organization, i.e. customers, investors, employees, suppliers, local communities, government organizations etc. Because of the specificity of the extractive industry the mining companies should consider especially such stakeholders as: employees, contractors, business partners, communities directly affected by mining operations, advocacy organizations, including religious and environmental groups as well as indigenous people. Identifying expectations of these stakeholder groups will broaden the mining companies' knowledge on possible impact of these groups on the company and will allow to increase the possible benefits as well as reduce the negative consequences of their activities.

An inseparable element of the CSR concept is the process of reporting on CSR performance. We can define corporate social responsibility reporting as the practice of providing information to external and internal stakeholders about the economic, environmental and social performance achieved by the organization over a given period of time.

Developing a CSR report is one of the way to communicate with stakeholders on how the company has implemented the social responsibility policy and to what extent the CSR goals have been achieved. Therefore, we can assume that CSR reporting is a process of disclosing information in a comprehensive manner about the company's CSR strategy, policy and results towards key stakeholder groups and the general public. The form of CSR reporting will depend on the company's communication strategy. These companies who want to build lasting relationship with the environment will treat the reporting of CSR aspects as a process of a two-way communication which means exchanging information and opinions with stakeholders. The two-way communication in the form of a dialogue in which both participants are demanding exchange of information from one another is the most expected situation as both participants are able to change the behavior. Despite the fact that one-way communication is necessary, it is not sufficient for effective communication of social responsibility. As stakeholder engagement in CSR management is of utmost importance receiving the feedback message is crucial in maintaining good relationships with company's stakeholders (Hąbek, and Brodny, 2017). Therefore it is important to invite the stakeholders to take part in developing CSR report (e.g. through the process of identification of materiality issues which should appear in the CSR report) as well as to give the feedback on the achieved CSR results disclosed in the report.

Currently, enterprises report CSR data in many different ways. Some of the reporters prepare separate CSR reports, some dedicate a special section on CSR in the annual report, and some prepare integrated reports presenting financial and non-financial data and their mutual impact in one report. When preparing a CSR report, companies can use international guidelines in this area or prepare a report according to their own concept. Regarding the form of the presentation, CSR reports can be available in electronic form in pdf format or in an interactive form available online, with the option of adjusting the report content to the needs of the interested party. CSR reports also differ with the reporting period. Some companies report in 
the annual cycle others in a two- or three-year cycle. In order to authenticate the data disclosed in CSR reports, some of the reporters decide to submit an external independent verification of the report.

\section{CSR reporting in mining context}

The global market for metal mining products is dominated by multi-national corporations that are mainly headquartered in the OECD countries, especially in Australia, Canada, Japan, UK and the United States. Corporations like the Canadian Goldcorp or the UK-based Rio Tinto have become responsible for more than $80 \%$ of the world's non-fuel mineral production (Dashwood, 2013). On the other hand the mining industry is responsible for significant damage to the natural environment and threats to human wellbeing. Due to increased pressure from different groups of stakeholders, mining companies have been more and more active in practicing the corporate social responsibility concept to address the various sustainability challenges of their operations (Mutti et al., 2012; Zasadzień, 2014). The growing awareness of the mining industry's bad reputation as a 'dirty business' through NGO activism is part of this move. The continued criticism from NGOs and fears of stricter, government-based regulations pushed multinational mining corporations to actively engage into sustainability issues and reporting using also a voluntary self-regulation scheme (Himley, 2010; Istvan, 2011). Currently we can distinguish several self-regulation initiatives dedicated specifically to the mining sector. This kind of instruments include, inter alia, the following: Initiative for Responsible Mining Assurance, International Council on Mining and Metals and Extractive Industries Transparency Initiative (see Table 1).

When considering sustainability reporting, mining corporations are using mainly the guidelines of the Global Reporting Initiative (GRI) and its mining sector supplement (Boiral, 2013; Fonseca, 2010). The GRI Standards are designed to help organizations communicate about their impacts on the economy, the environment, and society. The first version of the GRI Guidelines (G1) was published in 2000. From that time there was several changes introduced to the Guidelines which stem from the fact that they are subject to periodical reviews in order to ensure the best and the most up-to-date recommendations relating to effective sustainability reporting. The latest set of GRI Standards was developed in 2016 and now the standards include:

- 3 universal Standards, applicable to all organizations,

- 33 topic-specific Standards, organized into economic, environmental and social series.

Organizations select and use only the relevant topic-specific Standards, based on their material topics (GRI Standards, 2018). 
Table 1.

Initiatives of the mining sector focused on sustainability

\begin{tabular}{|l|l|}
\hline INITIATIVE & SCOPE \\
\hline $\begin{array}{l}\text { Global Mining } \\
\text { Sustainability (GMSu) }\end{array}$ & $\begin{array}{l}\text { Global Mining Sustainability (GMSu) is a communications platform integrating the } \\
\text { mining industry and society towards common sustainable goals. GMSu promotes } \\
\text { and disseminates training, projects management, multi-disciplinary skills access, } \\
\text { networking, news, and other service to advance it's goals. }\end{array}$ \\
\hline $\begin{array}{l}\text { International Council } \\
\text { on Metals and Mining } \\
\text { (ICMM) (self- } \\
\text { regulation) }\end{array}$ & $\begin{array}{l}\text { ICMM was established in 2001 and bring together 27 mining and metals companies } \\
\text { as well as 33 national and regional mining associations. The mission of the initiative } \\
\text { is to promote the concept of sustainable development in the mining industry by: }\end{array}$ \\
$\begin{array}{l}\text { - launch of SD Framework (adherence is condition of membership), } \\
\text { close collaboration with GRI to establish reporting criteria (GRI reporting } \\
\text { is mandatory for ICMM members), } \\
\text { commitment to independent third-party assurance. }\end{array}$ \\
\hline $\begin{array}{l}\text { Extractive Industries } \\
\text { (self-regulation) }\end{array}$ & $\begin{array}{l}\text { The Extractive Industries Transparency Initiative (EITI) is the global standard to } \\
\text { promote the open and accountable management of oil, gas and mineral resources. } \\
\text { The EITI Standard requires the disclosure of information along the extractive } \\
\text { industry value chain from the point of extraction, to how revenues make their way } \\
\text { through the government, and how they benefit the public. }\end{array}$ \\
\hline $\begin{array}{l}\text { Initiative for } \\
\text { Responsible Mining } \\
\text { Assurance (certification } \\
\text { scheme) }\end{array}$ & $\begin{array}{l}\text { IRMA's Standard for Responsible Mining was developed over ten years and in } \\
\text { consultation with more than 100 companies and organizations, covers all mined } \\
\text { materials, except for energy fuels, for all sizes of industrial mines and in all parts of } \\
\text { the world. The Standard defines good practices for what responsible mining should } \\
\text { look like at the industrial-scale. It provides the list of expectations that independent } \\
\text { auditors will use as the benchmark for responsible mines. }\end{array}$ \\
\hline
\end{tabular}

Source: based on information from https://responsiblemining.net, https://eiti.org/,

https://www.icmm.com/, https://globalminingsustainability.com/.

In 2010 Global Reporting Initiative has published sector supplement for sustainability reporting addressed to companies from mining and metals industry. The GRI Mining and Metals Sector Supplement is a sector-specific guidance including unique indicators for mining and metals industry and was designed to cover all main activities in the mining sector; exploration, mining and primary metal processing, including metal fabrication and recycling; and the complete project life cycle, from development through operational lifetime to closure (Jonek-Kowalska, 2014) and post-closure. The main contextual issues include (GRI Mining and Metals, 2010):

- the control, use, and management of land,

- the contribution to national economic and social development,

- community and stakeholder engagement,

- labour relations,

- environmental management,

- relationships with artisanal and small-scale mining,

- an integrated approach to minerals use.

To the existing GRI set of aspects and indicators it has been added four additional aspects in the category of social issues: artisanal and small scale mining, resettlements, closure planning, and materials stewardships. To the basic set of performance indicators it has been added eleven sector specific indicators (GRI Mining and Metals, 2010). The indicators refer to environmental and social aspects of sustainability reporting (see Figure 1). It must be noted 
here that GRI sector supplements are designed for use together with the GRI guidelines, and not instead of them (Hąbek, 2014).

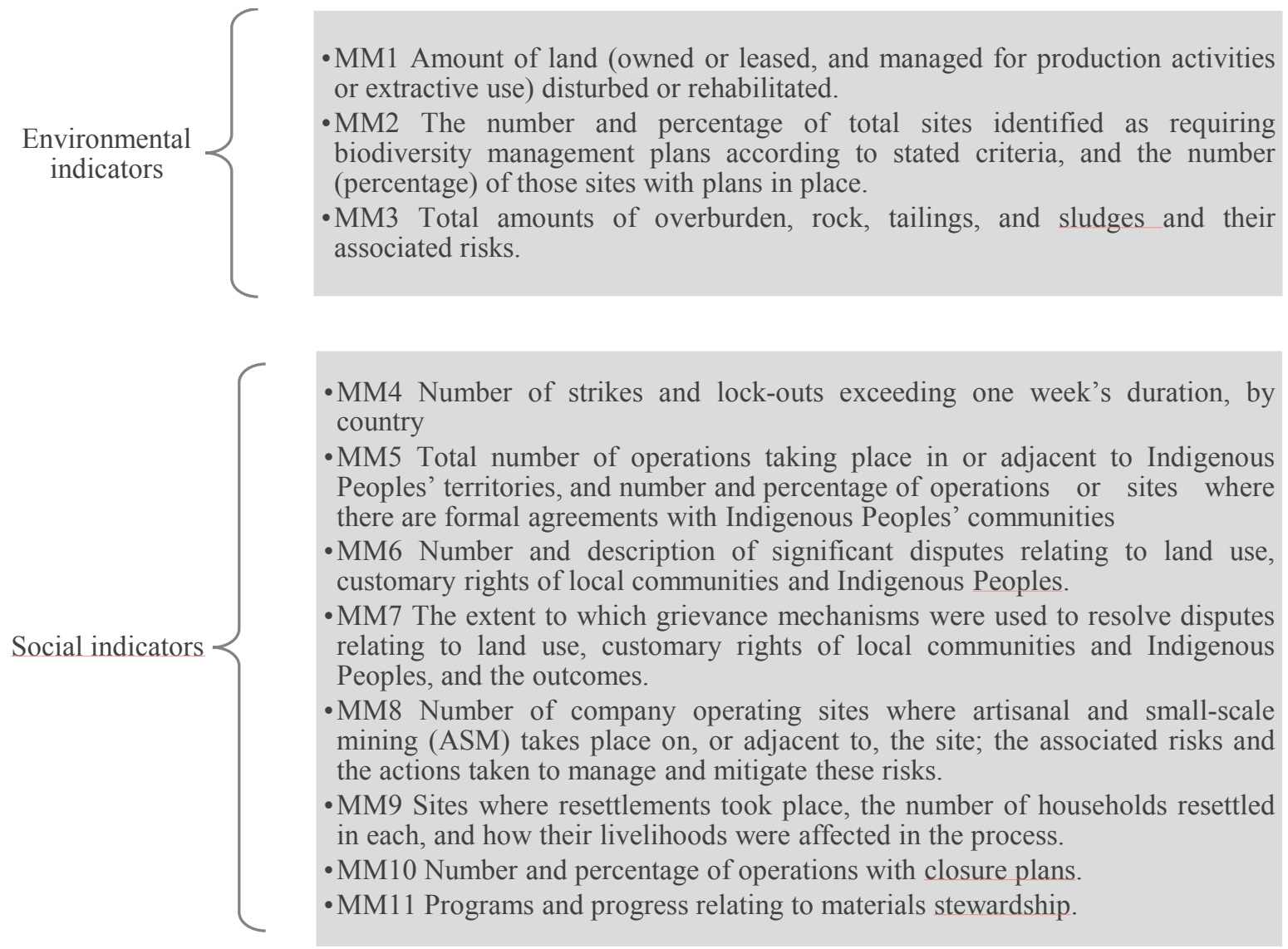

Figure 1. Sector specific indicators of Mining and Metals Sector Supplement. Source: based on Sustainability Reporting Guidelines and Mining and Metals Sector Supplement, GRI (2007). Retrieved from www.globalreporting.org, 28.11.2017.

According to the KPMG Survey of Corporate Responsibility Reporting mining belongs to the sectors with highest numbers of CSR reports and the reports of mining companies are recognized as documents of high quality (KPMG, 2013; KPMG, 2015). From 2010, a stable growth of reporting enterprises from mining sector can be observed at the global level as well as in individual regions. A significant increase in the number of CSR reports since 2016 can be noticed in Asia (see Table 2). In 2017, CSR reports from Europe accounted for $16 \%$ of all CSR reports developed by mining companies in the world (Table 2). It should be borne in mind that if we are taking into account voluntary CSR reporting every enterprise have a freedom to report in various cycles, sometimes two or three years period, hence it is difficult to refer to the number of CSR reports when analyzing a short period of time and differences may not result from the declining number of reporting companies but the adopted reporting strategy of particular enterprise. 
Table 2.

Number of CSR reports in mining sector by region

\begin{tabular}{|c|c|c|c|c|c|c|}
\hline \multirow[t]{2}{*}{$\begin{array}{l}\text { Year of } \\
\text { publication }\end{array}$} & \multicolumn{6}{|c|}{$\begin{array}{l}\text { Number of organizations from mining sector which published CSR report, } \\
\text { according to GRI database }\end{array}$} \\
\hline & Europe & Africa & Asia & $\begin{array}{l}\text { Latin America \& } \\
\text { Caribbean }\end{array}$ & $\begin{array}{l}\text { Northern } \\
\text { America }\end{array}$ & Oceania \\
\hline 2010 & 16 & 21 & 18 & 27 & 21 & 15 \\
\hline 2011 & 17 & 44 & 24 & 37 & 31 & 15 \\
\hline 2012 & 24 & 47 & 27 & 34 & 38 & 20 \\
\hline 2013 & 26 & 41 & 34 & 35 & 39 & 18 \\
\hline 2014 & 30 & 40 & 31 & 38 & 36 & 20 \\
\hline 2015 & 32 & 35 & 28 & 32 & 34 & 26 \\
\hline 2016 & 36 & 41 & 51 & 38 & 33 & 24 \\
\hline 2017 & 34 & 37 & 54 & 33 & 33 & 16 \\
\hline
\end{tabular}

Source: based on data from https://database.globalreporting.org/, 21.07.2019.

Having a glimpse on the latest available CSR reporting practices of mining sector in European Union we can notice that all reports published in 2017 (22 reports) was developed by multinational enterprises or large companies. All data has been obtained from GRI database (see Table 3).

Table 3.

Mining companies which published CSR report in 2017 in European Union

\begin{tabular}{|l|l|l|l|}
\hline Name of company & Size & Country & Type of report \\
\hline Acacia Mining & MNE & United Kingdom & Separate \\
\hline Anglo American & Large & United Kingdom & Separate \\
\hline ArcelorMittal Ostrava a.s. & MNE & Czech Republic & Separate \\
\hline Areva Mines & MNE & France & Separate \\
\hline Bellzone Mining & MNE & United Kingdom & Annual \\
\hline Boliden & Large & Sweden & Separate \\
\hline Eramet & MNE & France & Separate \\
\hline Evraz & MNE & United Kingdom & Annual \\
\hline Fresnillo & MNE & United Kingdom & Annual \\
\hline Gem Diamonds & Large & United Kingdom & Separate \\
\hline G.K. Lubelski Węgiel Bogdanka & Large & Poland & Integrated \\
\hline Hellas Gold & Large & Greece & Separate \\
\hline Hochschild Mining & MNE & United Kingdom & Annual \\
\hline Imerys & MNE & France & Separate \\
\hline LKAB & Large & Sweden & Annual \\
\hline Nordkalk & MNE & Finland & Separate \\
\hline Polymetal International plc & MNE & United Kingdom & Separate \\
\hline Randgold Resources Limited & Large & United Kingdom & Separate \\
\hline RHI & Large & Austria & Annual \\
\hline Rio Tinto & MNE & United Kingdom & Separate \\
\hline Vedanta Resources & Large & United Kingdom & Separate \\
\hline Weatherly International Plc & Large & United Kingdom & Annual \\
\hline Source: htps:/database.globalrep & ing.rg/. &
\end{tabular}

Source: https://database.globalreporting.org/.

Headquarters of $54 \%$ of the reporting enterprises are located in United Kingdom, $16 \%$ in France and 9\% in Sweden. The rest of the reporters are located in other EU member states: Czech Republic, Poland, Finland, Austria and Greece. More than half of the reports $(64 \%)$ were prepared as separate documents and 32\% of reporting enterprises disclose CSR data in annual reports with a section dedicated to CSR issues. Only one of the analysed 
report in 2017 was prepared as an integrated report - the report of Polish coal mine (Lubelski Węgiel Bogdanka S.A. As preparing integrated report is not so common among reporting companies it is worthy to present the content of this type of report. The integrated report of LW Bogdanka S.A. presents integrated value building model of the company which consists of six capital: financial, operational, human, intellectual, social and natural. As part of the financial capital the structure of capital ownership, corporate governance, internal control and risk management as well as selected financial results were discussed in the report. The chapter concerning the operating capital presents the business model, infrastructure and investments as well as integrated management system, CSR management and integrated risk management system. The chapter titled human capital contains information on the workplace and employment, safety, diversity, anti-discrimination and human rights, and issues related with the social dialogue and ethics as part of the organizational culture of LW Bogdanka S.A. The chapter on intellectual capital contains information on the company's involvement in technological innovations and presents cooperation with science and industry initiatives. The chapter on social capital presents how LW Bogdanka S.A. builds relations with stakeholders and pursues sustainable development goals. The chapter titled social capital presents also information about company's impact (economic impact, social involvement, charity activities, mining damage). The chapter dedicated to natural capital discusses the company's impact on the environment (biosphere, water management, waste management, consumption of materials and raw materials, energy and emissions) as well as issues concerning legal compliance and environmental fees. The integrated report of LW Bogdanka S.A. ends with basic financial results and indicators consistent with the GRI guidelines.

Analysing reports of the mining companies, it is worth mentioning here that in 2016 (report of results from 2016 was published in 2017) large enterprises in European Union were not yet obliged to disclose non-financial information in order to comply with the new disclosure requirements of the EU Directive. Therefore all the reports mentioned in the paper was created on voluntary basis.

\section{Mandating CSR reporting at EU level}

Governments across the world have capabilities to shape appropriate behavior amongst companies, including reporting data on corporate social responsibility. It is possible to distinguish numerous initiatives which can be undertaken by governmental agencies in order to support and promote such kind of reporting. These initiatives may include for example activities focused on informing and sharing the knowledge in the form of guidelines, websites and conferences dedicated CSR reporting as well as activities related with dissemination of the best practices. Such type of reporting can also be developed by governmental support of research 
conducted within this area. An example of such initiatives are the activities of the Danish government to support research on the effect of established legal requirements for disclosure of data on the CSR (Danish Business Authority, 2013). The activity level of government agencies maybe evidenced in many different ways. Further in this section the mandating activities will be subject to analysis and especially the Directive of the European Parliament and of the Council (2014/95/EU).

Mandating actions are these types of governmental actions which relate to the ability to legally mandate reporting of CSR requirements or introducing sanctions in the event of nondisclosure or false disclosures in this regard. These legal provisions can set precise standards for corporate reporting, including lists of indicators, formats for reporting, and frequency of reporting. Governments can then monitor this process of reporting, both by evaluating reporting data and comparing it to physical inspections of facility performance. Government agencies can also work to ensure the quality of reported data by requiring external, third-party verification procedures, quality assurance standards, and regulations for auditors of CSR reports. Governments can also mandate sanctions for non-disclosure or false disclosures of CSR data to create incentives for full and accurate reporting (IIED, 2002). Voices supporting the introduction of legal regulations in regard to CSR reporting are related to the fact that enterprises should be obliged to prepare CSR reports, as otherwise they will not report voluntarily and information disclosed by companies is incomplete and of little value to stakeholders (Doane, 2008).

The European Parliament, in its two resolutions entitled, respectively, "Corporate Social Responsibility: accountable, transparent and responsible business behavior and sustainable growth" (COM, 2013) and "Corporate Social Responsibility: promoting society's interests and a route to sustainable and inclusive recovery" (Report on CSR, 2013) identified the need to raise the transparency in this area and invited the Commission to bring forward a legislative proposal. It has been confirmed that the approach to the disclosure of non-financial information in the Accounting Directives has not been sufficiently effective. A majority of stakeholders consulted considered that the obligation set by the Accounting Directives lacks clarity and may prejudice legal certainty (Costa, and Agostini, 2016). Some Member States have developed national legislation that goes beyond the requirements of the Accounting Directives. However, national requirements were significantly diverse, which added to the lack of clarity for companies and investors who operate across the Internal Market. Some Member States target large companies, while others focus on certain listed companies or government-owned companies only. Some Member States refer to international guidelines (although often different ones), while others were developing their own national reporting guidelines (Directive proposal, 2013).

In order to enhance the consistency and comparability of non-financial information disclosed throughout the European Union on 22 October 2014, a new Directive of the European Parliament and of the Council (2014/95/EU) was adopted. The Directive obliges certain large 
undertakings to prepare a non-financial statement containing information relating to at least environmental matters, social and employee-related matters, respect for human rights, anti-corruption and bribery matters (see Table 4). Such a statement should include a description of the policies, outcomes and risks related to those matters and should be included in the management report of the undertaking concerned (Directive 2014/95/EU, 2014). The obligation to disclose a non-financial statement apply only to those large undertakings which are publicinterest entities and to those public-interest entities which are parent undertakings of a large group, in each case having an average number of employees in excess of 500, in the case of a group on a consolidated basis. These companies are obliged to comply with the new disclosure requirements of the locally transposed laws by 2018 (Directive 2014/95/EU, 2014).

\section{Table 4.}

The scope of the non-financial statement in accordance with the Directive of the European Parliament and of the Council 2014/95/EU of 22 October 2014

\begin{tabular}{|c|c|}
\hline \multicolumn{2}{|c|}{$\begin{array}{l}\text { The scope of a non-financial statement in accordance with the Directive of the European Parliament } \\
\text { and of the Council 2014/95/EU of } 22 \text { October } 2014\end{array}$} \\
\hline With regard to environmental issues: & With regard to social and employee-related matters: \\
\hline $\begin{array}{l}\text { - details of the current and foreseeable } \\
\text { impacts of the undertaking's operations on } \\
\text { the environment, and, as appropriate, on } \\
\text { health and safety, } \\
\text { - information on the use of renewable and/or } \\
\text { non-renewable energy, } \\
\text { - information on greenhouse gas emissions, } \\
\text { - information on water use and air pollution. }\end{array}$ & $\begin{array}{l}\text { - information on the actions taken to ensure gender equality, } \\
\text { - information on the implementation of fundamental } \\
\text { conventions of the International Labour Organisation, } \\
\text { - information on working conditions, } \\
\text { - information on social dialogue, } \\
\text { - information on respect for the right of workers to be } \\
\text { informed and consulted, } \\
\text { - information on respect for trade union rights, } \\
\text { - information on health and safety at work, } \\
\text { - information on the dialogue with local communities, } \\
\text { and/or the actions taken to ensure the protection and the } \\
\text { development of those communities, } \\
\text { - with regard to human rights, anti-corruption and bribery, } \\
\text { the non-financial statement could include information on } \\
\text { the prevention of human rights abuses and/or on } \\
\text { instruments in place to fight corruption and bribery. }\end{array}$ \\
\hline
\end{tabular}

Source: developed on the basis of Directive 2014/95/EU of the European Parliament and of the Council of 22 October 2014 amending Directive 2013/34/EU as regards disclosure of non-financial and diversity information by certain large undertakings and groups, Retrieved from http://eur-lex.europa.eu/legalcontent/en/TXT/?uri=CELEX\%3A32014L0095, 27.09.2018.

The Directive indicates that enterprises in providing the information may rely on national frameworks, Union-based frameworks such as the Eco-Management and Audit Scheme (EMAS), or international frameworks such as the United Nations (UN) Global Compact, the Guiding Principles on Business and Human Rights implementing the UN 'Protect, Respect and Remedy' Framework, the Organisation for Economic Co-operation and Development (OECD) Guidelines for Multinational Enterprises, the International Organisation for Standardisation's ISO 26000, the International Labour Organisation's Tripartite Declaration of principles concerning multinational enterprises and social policy, the Global Reporting Initiative, or other recognized international frameworks (Directive 2014/95/EU, 2014). 
The Directive 2014/95/EU also mentions the topic of independent verification of disclosed non-financial data. Statutory auditors and audit firms should only check that the non-financial statement or the separate report has been provided. In addition, it should be possible for Member States to require that the information included in the non-financial statement or in the separate report be verified by an independent assurance services provider.

After the transposition process we can notice that in individual Member States requirements of the national law concerning non-financial reporting are not the same as in the Directive but they are adapted. It concerns for example such crucial issues as report topics and content, reporting framework or disclosure format (CSR Europe and GRI, 2017). As we are able to identify differences between the national-level transpositions of the Directive across Member States the question rises if it is a real step forward to standardisation of CSR reporting at EU level. The time is needed to give the answer.

\section{Conclusions}

The mining industry plays an important role in economic and industrial development of many countries all over the world. Therefore, the consumption of minerals and metals has grown over the last years, among others. Despite the positive role of the mining's sector we cannot forget about its adverse impact. The bad reputation of the mining industry and criticism of its operations by different groups of stakeholders have led to more interests and different initiatives among mining companies to conduct more sustainable operations. The mining industry has participate or/and initiate some voluntary self-regulation schemes to become more transparent and disclose how responsibly they run their operations. As a result of the global move towards the transparency and sustainability the practice of the corporate social responsibility reporting is more and more often used by mining companies. At the European Union level a Directive 2014/95/EU on non-financial disclosure has been adopted which obliged certain large enterprises do disclose data related to CSR concept. This article discusses the Directive as large and multinational mining enterprises are covered by its provisions. The directive was created to enhance the consistency and comparability of non-financial information disclosed throughout the European Union. However, it seems, that this is only a step towards true standardization because despite the obligation to report, the Directive leaves a lot of freedom to reporters, not to say too much. The first problem may arise with the fact that the reporting companies may rely on different national and international frameworks concerning separately each of the reporting area (environment, social, employees matters). This freedom of choice make it impossible to compare non-financial reports even within the sector. Questionable is also the issue of independent verification of the reports. Individual Member States may decide if the third party verification is mandatory or not and if mandatory 
the auditors should only check if the non-financial statement or the separate report has been provided. Therefore the credibility of information disclosed in such reports is doubtful. The EU Directive 2014/95/EU is the first step but there is a need for further steps directed towards unifying the principles and content of non-financial statements and getting the CSR reporting practices closer to financial ones to guarantee the reliability of the data disclosed in these areas.

\section{References}

1. Bluszcz, A. (2017). Ecological Growth Boundaries. Management Systems in Production Engineering, 25(1), 55-59.

2. Boiral, O. (2013). Sustainability Reports as Simulacra? A Counter-Account of A and A+ GRI Reports. Accounting, Auditing \&Accountability Journal, 26(7), 1036-71.

3. COM, (2013). Retrieved from http://eur-lex.europa.eu/LexUriServ/LexUriServ.do?uri= COM:2013:0207:FIN:EN:PDF, 20.10.2018.

4. Costa, E., Agostini, M. (2016). Mandatory Disclosure about Environmental and Employee Matters in the Reports of Italian-Listed Corporate Groups. Social and Environmental Accountability Journal, 36(1), 10-33. DOI: 10.1080/0969160X.2016.1144519.

5. CSR Europe and GRI (2017). Member State Implementation of Directive 2014/95/EU. A comprehensive overview of how Member States are implementing the EU Directive on Non-financial and Diversity Information, Retrieved from https://www.globalreporting.org/ resourcelibrary/NFRpublication\%20online_version.pdf, 20.10.2018.

6. Danish Business Authority (2013). Corporate Social Responsibility and Reporting in Denmark: Impact of the third year subject to the legal Requirements for reporting on CSR in the Danish Financial Statements Act, the results of the research can be download from the government website, Retrieved from www.csrgov.dk, 28.07.2019.

7. Dashwood, H.S. (2013). Sustainable Development and Industry Self-Regulation: Developments in the Global Mining Sector. Business \& Society. DOI: 10.1177/ 0007650313475997.

8. Directive 2014/95/EU of the European Parliament and of the Council of 22 October 2014 amending Directive 2013/34/EU as regards disclosure of non-financial and diversity information by certain large undertakings and groups, Retrieved from http://eur-lex.europa.eu/legal-content/en/TXT/?uri=CELEX\%3A32014L0095, 27.09.2017.

9. Directive Proposal (2013). Proposal for a DIRECTIVE OF THE EUROPEAN PARLIAMENT AND OF THE COUNCIL amending Council Directives 78/660/EEC and $83 / 349 /$ EEC as regards disclosure of non-financial and diversity information by certain 
large companies and groups, Retrieved from https:/eur-lex.europa.eu/legal-content/ EN/ALL/?uri=CELEX\%3A52013PC0207, 28.07.2019.

10. Doane, D. (2008). Corporate Spin: The Troubled Teenage Years of Social Reporting. London: New Economics Foundation.

11. Euromines (2018). Before it's yours we mine it. Industry 4.0, European Association of Mining Industries, Metal Ores \& Industrial Minerals, Retrieved from http://www.euromines.org/publications.

12. Extractive Industries Transparency Initiative. Available online https://eiti.org/, 27.07.2019.

13. Fonseca, A., McAllister M.L., Fitzpatrick, P. (2012). Sustainability Reporting among Mining Corporations: A Constructive Critique of the GRI Approach. Journal of Cleaner Production, 12. DOI: 10.1016/j.jclepro.2012.11.050.

14. Global Mining Sustainability. Available online https://globalminingsustainability.com/, 27.07.2019.

15. GRI Mining and Metals Sector Supplement. Retrieved from https://www.icmm.com/en-gb/ publications/commitments/gri-mining-and-metals-sector-supplement, 27.07.2019

16. GRI Standards (2018). Introduction to the GRI Standards, Webinar 1 of the six-part GRI Standards in Practice Series. Retrieved from https://www.globalreporting.org, 28.07.2019.

17. Hąbek, P. (2014). Sustainability reporting in mining industry. 14th GeoConference on Ecology, Economics, Education and Legislation, 407-414.

18. Hąbek, P., Brodny, J. (2017). Corporate Social Responsibility Report - an Important Tool to Communicate with Stakeholders. Proceedings of "4th International Multidisciplinary Scientific Conference on Social Sciences \& Arts SGEM 2017. Business and Management, 241-248.

19. Himley, M. (2010). Global Mining and the Uneasy Neoliberalization of Sustainable Development. Sustainability, 2(10), 3270-90.

20. http://www.euromines.org/mining-europe, 26.07.2019.

21. IIED (2002). International Institute for Environment and Development, Baseline Study of Public Sector Roles in Strengthening Corporate Social Responsibility. Document prepared for: Corporate Social Responsibility Program, Washington, D.C.: World Bank.

22. Initiative for Responsible Mining Assurance. Available online https://responsiblemining.net, 27.07.2019.

23. International Council on Mining and Metals. Available online https://www.icmm.com/, 27.07.2019.

24. Istvan, E. (2011). The Curse of the Gold: Discourses Surrounding the Project of the Largest Pit- Mine in Europe. Human Geographies - Journal of Studies and Research in Human Geography, 5(2), 57-68.

25. Jenkins, H. (2004). Corporate social responsibility and the mining industry: Conflicts and constructs. Corporate Social Responsibility and Environmental Management, 11(1), 23-34. DOI: $10.1002 /$ csr.050. 
26. Jonek-Kowalska, I. (2014). Risk management in the hard coal mining industry: Social and environmental aspects of collieries' liquidation. Resources Policy, 41, 124-134, DOI: 10.1016/j.resourpol.2014.05.002.

27. Kuźbik, P. (2010). Komunikacja społecznej odpowiedzialności w praktyce organizacyjnej. Acta Universitatis Lodziensis, Folia Oeconomica, 234, 421-429.

28. Midor, K., Biały, W., Wodarski, K. (2017). Postrzeganie górnictwa węgla kamiennego przez samorządy lokalne. IV Polski Kongres Górniczy, Kraków, 20-22.11.2017, CD-ROM.

29. Mutti, D., Yakovleva, N., Vazquez Brust, D., and Di Marco, M.H. (2012). Corporate social responsibility in the mining industry: Perspectives from stakeholder groups in Argentina. Resources Policy, 37(2), 212-222.

30. OECD (2011). OECD Green Growth Studies: Energy, http://www.oecd.org/greengrowth/.

31. Peck, P., \& Sinding, K. (2003). Environmental and social disclosure and data richness in the mining industry. Business Strategy and the Environment, 12(3), 131-146. doi: $10.1002 /$ bse. 358 .

32. Prior, T., Giurco, D., Mudd, G., Mason, L., \& Behrisch, J. (2012). Resource depletion, meak minerals and the implications for sustainable resource management. Global Environmental Change, 22, 577-587. DOI: 10.1016/j.gloennvcha.2011.08.009.

33. Report on CSR (2013). Retrieved from http://www.europarl.europa.eu/sides/ getDoc.do? type $=$ REPORT\&reference $=$ A7-2013-0023\&language $=E N$, 19.06.2019.

34. Sustainability Disclosure Database. Available online https://database.globalreporting.org/, 28.07.2019.

35. The KPMG (2013). Survey of Corporate Responsibility Reporting. Retrieved from https://assets.kpmg.com/content/dam/kpmg/pdf/2015/08/kpmg-survey-of-corporateresponsibility-reporting-2013.pdf, 17.03.2019.

36. The KPMG (2015). Survey of Corporate Responsibility Reporting. Retrieved from https://assets.kpmg.com/content/dam/kpmg/pdf/2016/02/kpmg-international-survey-ofcorporate-responsibility-reporting-2015.pdf, 17.03.2019.

37. Vurro, C., and Perrini, F. (2011). Investigating the accountability dynamics underlying effective CSR disclosure. In: A. Tencati, and F. Perrini, (Eds.), Business Ethics and Corporate Sustainability. Cheltenham: Edward Elgar Publishing Ltd, 195-210.

38. Wolniak, R. (2017). The Corporate Social Responsibility Practices in Mining Sector in Spain and in Poland - Similarities and Differences. Zeszyty Naukowe Politechniki Ślaskiej, Organizacja i Zarzadzanie, 111, 111-120.

39. Zasadzień, M. (2014). Social Evaluation of Mining Activity Effects. Geoconference on Science and Technologies in Geology, Exploration and Mining, SGEM 2014. Vol. III, Book Series: International Multidisciplinary Scientific GeoConference-SGEM, 545-552. 